\title{
VAN WAAR MOET HET WATER KOMEN VOOR EENE WATERLEIDING TE PARAMARIBO?
}

DOOR

DR. J. W. JENNY WEIJERMAN

In mijn artikel in de W. I. Gids van 1923, bladzijde 295, berekende ik het bedrag dat jaarlijks ontvangen zou moeten worden om eene waterleiding te Paramaribo tot eene economisch bestaanbare, niet bij voortduring noodlijdende onderneming te maken. Nadien heb ik van meer dan ééne, naar ik zeker weet betrouwbare, zijde vernomen dat dit bedrag de draagkracht der bevolking niet te boven ging. Dit is van groot gewicht, want economisch mogelijk zijnde, is nu de aanleg dezer waterleiding een sociaal en hygiënisch werk, dat om velerlei redenen ten spoedigste uitgevoerd behoort te worden.

Terwijl bij den aanleg eener waterleiding in Paramaribo geene bijzondere technische moeielijkheden overwonnen zullen behoeven te worden, moet evenwel groote aandacht worden gewijd aan de keuze der waterwinplaats. Want indien men ten volle de verbetering der volksgezondheid, die beoogd wordt, wil bereiken, zal met den aanleg der leiding gepaard moeten gaan het Overheidsbevel om alle thans bestaande middelen van watervoorziening, als zijnde minderwaardige, op te ruimen. Maar dit bevel zal alleen door de Overheid gegeven kunnen worden indien zij, naar menschelijke berekening, de zekerheid bezit dat de waterleiding in alle toekomst, zonder haperen en in ruim voldoende mate, drinkwater zal leveren van minstens even goede hoedanigheid als het thans voor de bevolking beschikbare. Anders toch zou Overheidsdwang zedelijk niet verantwoord zijn, want het in gebreke blijven van de waterleiding zou dan eene onoverzienbare 
ramp over de plaats brengen. En nu dreigt er in dit opzicht, als ik goed zie, eenig gevaar.

Verschillende plaatsen zijn voor en na genoemd geworden als geschikt om aldaar het voor Paramaribo noodige water te winnen. Mij zijn bekend geworden:

$1^{\circ}$. de diepere bodemlagen onder de plaats;

$2^{\circ}$. de schelprits, zich uitstrekkende onder en westelijk van de stad tot ongeveer aan de Saramacca;

$3^{\circ}$. de Tawajariezwamp;

$4^{\circ}$. de Para;

$5^{\circ}$. de Saramacca;

$6^{\circ}$. de Savannen of hare uitlóopers.

Ik zal mij veroorloven omtrent elk dezer winplaatsen enkele opmerkingen te maken.

$1^{\circ}$. Wat de diepere bodemlagen betreft, wordt sterk naar voren gebracht dat, als het mogelijk zou zijn daaruit het water te verkrijgen, de benoodigde buisleidingen, door het vervallen van lange transportleidingen, korter konden zijn en dat ook geen personeel zou behoeven te wonen in een weinig aantrekkelijk, afgelegen oord. Beide voordeelen zouden leiden tot verminderde kosten van aanleg en exploitatie. Dit moet worden toegegeven. Maar er staan tegenover deze voordeelen zoodanige groote nadeelen, althans kwade kansen, dat ik mij verplicht acht te waarschuwen! Waterwinning uit den dieperen ondergrond zou, naar ik meen, alleen in nadere overweging genomen mogen worden als alle andere mogelijkheden uitgeput zijn.

Wat toch is het geval? Onderscheiden moet worden, als men over diepboringen te Paramaribo spreekt, tusschen de diepere aardlagen (voornamelijk zand- en kleilagen) en het daaronder liggende oorspronkelijke gesteente, zijnde graniet. Bij het aanbevelen van artesische boringen om in de behoefte van water te Paramaribo te voorzien, steunt men voornamelijk op de uitkomsten, welke met dergelijke boringen in het naburige Demerara verkregen zouden zijn. Het is mij dusver niet gelukt om volledige gegevens te ver krijgen over wat aldaar is bereikt. Ik weet dus niet of het daar aangeboord water uit het graniet komt of uit hooger 
liggende lagen. In het Rapport betreffende de drinkwatervoorziening van Paramaribo, dat onder dagteekening van 15 Maart 1916 is uitgebracht door den Directeur van het Departement van Openbare werken en verkeer in Suriname vond ik evenwel alreeds het navolgende, waarop ik meen de aandacht te moeten vestigen, over den aard van dit water:

„De temperatuur van het water bedroeg bij beide genoemde boringen te Georgetown rond $90^{\circ}$ Fahrenheit of $32^{\circ}$ Celsius."

Zeer wel wetende dat ook het rivierwater in de tropen eene vrij hooge temperatuur pleegt te hebben en dat dus eene rivierwaterleiding te Paramaribo niet zal kunnen leveren het koele water, dat in Nederland de goede waterleidingen leveren; alsmede dat in Oost-Indië sommige waterleidingen ook wel water van $32^{\circ} \mathrm{C}$. of hooger nog leveren of althans geleverd hebben, vóórdat zij werden verbeterd - toch meen ik er de aandacht op te moeten vestigen dat het artesisch water te Paramaribo wellicht nog een aantal graden hooger in temperatuur zou zijn dan rivierwater en dit acht ik, als blijvende toestand, niet de meest gewenschte. Uit dien hoofde acht ik het voorbeeld van Georgetown niet dadelijk navolgenswaardig.

Maar er is grooter bezwaar nog. Het gevaar dat bronnen, die het water opbrengen uit den ondergrond van $\mathrm{Pa}-$ ramaribo, plotseling zout water zullen gaan leveren, is nimmer uit te sluiten. Hierop wezen ook reeds de heeren van Hasselt en Hoogesteger in hun „Voorloopig rapport inzake de drinkwatervoorziening voor de stad Paramaribo", uitgebracht op 7 November 1909, waarin zij schrijven:

„Het komt ons daarom voor, dat afgezien moet worden om door middel van diepboringen in de stad Paramaribo of de omgeving eene oplossing van het vraagstuk te vinden.

Het gevaar van binnendringend brak-, resp. zout water van de zeezijde is bovendien bij dergelijke diepboringen zeer groot.

Diepboringen tot diep in het graniet, om misschien een watergevende scheur te treffen, komen ons in verband met de groote kosten er van te speculatief voor, waarbij eveneens het gevaar van verzouting van de zeezijde blijft bestaan." 
Er zijn bovendien nog andere, door reeds verrichte onderzoekingen verkregen aanwijzingen dat het niet raadzaam is om het water voor eene waterleiding aan den ondergrond van Paramaribo te onttrekken. In 1903 is op het Sivaplein te Paramaribo reeds eene diepboring gedaan, gaande tot $164,50 \mathrm{M}^{1}$. onder maaiveld. Over de bij deze boring verkregen uitkomsten heb ik nergens nog volledige gegevens kunnen vinden. Toch heb ik alreeds in het „Verslag over de uitkomsten verkregen bij een aantal ondiepe boringen te Paramaribo in verband met de drinkwatervoorziening", hetwelk op 17 April 1907 werd uitgebracht door den Leider der Mijnexploratie van Gouvernementswege, den heer E. Middelberg, het navolgende gevonden dat de aandacht verdient:

„Weliswaar heeft de artesische boring op het Sivaplein water geleverd dat na een betrekkelijk eenvoudige bewerking (ontijzering) als „goed” kon worden gekwalificeerd, doch de beschikbare hoeveelheid is eenerzijds zoo gering, (8 à $10 \mathrm{~L}$. per minuut) en de kansen tot het verkrijgen van grootere hoeveelheden op grooter diepte, alhoewel niet uitgesloten, met het oog op het thans verkregen resultaat en in verband met de bodemformatie zoo weinig gunstig dat alvorens over te gaan tot het doen van aanzienlijke uitgaven dit punt nadere overweging vereischt."

Wat hier gezegd wordt over de geringe hoeveelheid water, die verkregen werd, wordt volkomen duidelijk uit wat de heeren van Hasselt en Hoogesteger in hun meergenoemd rapport zeggen:

„Het artesisch water, resp. diep-grondwater onder Paramaribo moet dus uit het zuidelijk heuvelland, hetwelk ca. 40 K.M. ten Zuiden van Paramaribo aanvangt, aangevoerd worden.

$\mathrm{Nu}$ zijn de aangeboorde grondlagen zoo moeilijk waterdoorlatend, dat niet verwacht kan worden, dat water in voldoende hoeveelheid over zulk een afstand aangevoerd zal worden.

Deze beschouwing is geheel in overeenstemming met de feiten, bij de diepboring op het Sivaplein waargenomen."

Maar van meer beteekenis nog acht ik thans dat men het aangeboorde water slechts met ,goed" kan kwalificeeren. Zoo aanstonds zal nader blijken dat men dusver in Suriname water met een veel te hoog zoutgehalte 
„goed” placht te noemen. „Goed” beteekent daar kennelijk niet meer dan ,iets minder slecht”.

Over de boring op het Sivaplein vond ik nog eene andere mededeeling, die duidelijk in dezelfde richting wijst. In de W. I. Gids van Juli 1926 schrijft de heer Apotheker D. G. J. Bolten, die destijds in de kolonie verbleef en aldaar een groot aantal watermonsters scheikundig heeft onderzocht - zijnde hij een erkend bekwaam onderzoeker - :

„De diepe boring (tot 164,5 M.) in 1903 op het Sivaplein door Mr. Wardle ${ }^{1}$ ) leverde of $z o u t^{2}$ ) ò sterk ijzerhoudend water in niet overmatig groote hoeveelheid."

Ik herhaal dat ik alsnog niet beschik over alle gegevens omtrent de diepboringen in Demerara en die in Paramaribo, maar wat mij dusver bekend werd, noopt mij tot de boven neergeschreven waarschuwing.

Het behoeft wel geen uitvoerig betoog, dat het verzouten - onherstelbaar verzouten! - van de bronnen eener waterleiding een ramp met groote gevolgen zou zijn. In Suriname, dat reeds zoo vaak tegenslag heeft ondervonden, mag men dergelijk risico niet loopen.

$2^{\circ}$. Door den heer Bolten is in een artikel in de W. I. G. van Juli 1926 de aandacht gevestigd op de schelprits, die zich uitstrekt van de Suriname-rivier naar de Saramacca en waarop een deel van Paramaribo is gebouwd.

Naar zijne meening zou deze schelprits eene goede waterwinplaats voor eene waterleiding zijn.

Over deze schelprits zeggen de heeren van Hasselt en Hoogesteger in hun meergenoemd Rapport alreeds het volgende:

„Deze schelpritsen zijn plaatselijke geringe verhoogingen in de lage zeer vlakke kustformatie.

1) Dit is waarschijnlijk eene vergissing. Wardle verrichtte in 1907, als particulier, een tweetal boringen, die slechts tot $\pm 50 \mathrm{M}$ gingen en geen succes hadden. Zie Rapport betreffende de drinkwatervoorziening van den Directeur van het Departement van Openbare werken en Verkeer, boven reeds meer genoemd.

$\left.{ }^{2}\right)$ Ik cursiveer. 
Zoo is o.a. het noordelijk deel van de stad Paramaribo op eene schelprits gebouwd, welke bij eene grootste breedte van ca. 300 à $400 \mathrm{M}$. eene grootste dikte van 4.50 à $3 \mathrm{M}$. bezit.

(Zie de ondiepe boringen behoorende tot het rapport van den ingenieur E. Middelberg dd. 17 April 1907).

Volgens de kaart van W. L. Loth (Kaart van Suriname naar de opmetingen van J. F. A. Cateau van Roosevelt en J. F. A. E. van Lansberge, aangevuld tot 1898 met die van en geteekend door W. L. Loth, Gouvernements-Landmeter in Suriname. Schaal 1 : 500,000. Uitgegeven bij J. H. de Bussy, Amsterdam, 1899) loopt deze schelprits ongeveer $10 \mathrm{~K}$.M. ten zuiden van de kustlijn, nagenoeg parallel aan de kustlijn, in de richting oostwest, vanaf het Fort Zeelandia te Paramaribo tot aan de Saramacca rivier.

Deze schelpritsen zijn plaatselijke betere infiltratiegebieden dan de onmiddellijke omgeving ervan.

In het algemeen leveren de putten, welke in de schelpritsen aangelegd zijn, beter grondwater dan die welke in het fijne alluviale zand gezonken zijn.

Het komt ons echter voor, dat deze schlepformatie van te geringen omvang is, vooral wat de dikte betreft om daar veilig de watervoorziening van Paramaribo op te baseeren.

De voorraad grondwater in de schelprits zal in den drogen tijd spoedig uitgeput zijn, waardoor het gevaar ontstaat, dat minder goed water van de naastliggende gronden en zwampen in de schelprits zal dringen en voorts het brakke water van onderop in de schelprits zal opdringen."

Bovenstaande bedenkingen verdienen overweging.

Voor zoover de heer Bolten aan deze schelprits water zou willen onttrekken binnen de bebouwde kom, zou ik daartegen bovendien bezwaren van hygiënischen aard willen inbrengen. Ook bij de snelle mineralisatie van allen organischen afval in de tropen, moet toch worden gevreesd dat bij de geweldige afpomping, die noodig zou zijn, om eene hoeveelheid van $4000 \mathrm{M}^{3}$ en later misschien nog meer, dag aan dag aan deze laag te onttrekken, het snel toestroomende water uit de omgeving nog niet geheel ontlede afvalproducten der menschelijke huishouding zou medevoeren.

Eenigszins anders sta ik, na een langdurig onderhoud met hem, tegenover het voorstel van den heer Bolten, om 
het water aan deze schelprits te onttrekken, voor zoover zij buiten de stad, in maagdelijk terrein, gelegen is. Althans zou ik meenen dat, wegens het gewicht der zaak, het eenvoudige onderzoek ingesteld behoorde te worden, hetwelk de heer Bolten voorstelt in de W. I. Gids 1926, blz. 123, waar hij schrijft:

„Op domeingrond bijv. achter „Kwatta” worden op eenige plaatsen in de schulprits aan de Noordzijde proefwatervangen gegraven, bestaande:

$1^{\circ}$. uit een put, die zoo ver mogelijk in de schelpenlaag doordringt, met een grondvlak van 0,5 tot 1,0 vierkante meter. Deze put moet machinaal leeggepompt kunnen worden.

$2^{\circ}$. aan deze put verbindt men een iets hooger gelegen kanaal, evenwijdig aan de lengte-as van de rits met een breedte op den bodem, bijv. van 30-50 c.M., eerst $5 \mathrm{M}$. later 10, 15, 20, 25, enz. Meter lang. Telkens wordt van elk nieuw gegraven stuk het debiet opgenomen. $\mathrm{Na}$ eenige dagen pompen wordt van het water eene analyse gemaakt door den militair apotheker belast met den keuringsdienst van levensmiddelen te Paramaribo."

Echter ben ik het volstrekt oneens met hem, waar hij verder zegt:

„Bij de beoordeeling heeft men vooral er op te letten of het water smakelijk is. Een streng vasthouden aan den eisch dat er niet meer dan eene bepaalde hoeveelheid keukenzout in aanwezig mag zijn heeft geen zin, mits er niet zooveel aanwezig zij dat het water beslist zout smaakt."

Water met een zoutgehalte van $200-300$ m.Gr. per liter moge drinkbaar zijn, als evenwel eene centrale drinkwatervoorziening te Paramaribo niet anders dan dergelijk water kan leveren, wordt zij beter niet aangelegd. Dan is het regenwater misschien van tijd tot tijd op, maar als het er is, veel beter.

Ook de heeren van Hasselt en Hoogesteger zijn in hun reeds vroeger genoemd Voorloopig rapport van dezelfde meening. Zij zeggen:

„Ten opzichte van het zoutgehalte wenschen wij nog de volgende opmerking te maken. Bij de beoordeeling van de aan drink- 
water te stellen eischen, blijkt uit de rapporten dat men ten opzichte van het zoutgehalte noodgedwongen de eischen later veel lager heeft gesteld dan bij den eersten opzet. Nog daargelaten of een zoutgehalte liggende tusschen 100 en 500 m.Gr. per Liter het water even geschikt doet zijn voor het gebruik, als wanneer men beneden de $100 \mathrm{~m}$.Gr. blijft, zoo is water met dergelijk hoog zoutgehalte toch zeker af te raden voor eene waterleiding, waarbij het water in ijzeren buizen moet vervoerd worden en zulks met het oog op snelle roestvorming."

$3^{\circ}$. Omtrent de Tawajariezwamp vond ik het navolgende in het Rapport betreffende de drinkwatervoorziening van Paramaribo, uitgebracht door den Directeur van het Departement van Openbare werken en Verkeer.

„Op aandrang van uit de Kolonie is toen door den Minister van Koloniën aan genoemde deskundigen nog verzocht een nader rapport uit te brengen omtrent de mogelijkheid om als prise d'eau voor de waterleiding te gebruiken een der groote zwampen bij de stad gelegeñ, omdat daarvan een beteekende besparing van kosten het gevolg kon zijn.

Aan dit verzoek is gevolg gegeven door den heer van Hasselt bij schrijven van 19 December 1910. Volgens diens meening zou de Tawajariezwamp wel geschikt als prise d'eau zijn te benutten; het water is van goede hoedanigheid en door chemische middelen gemakkelijk van zijn bruine kleur te ontdoen. De kosten van dit plan werden globaal op $f$ 950.000. - gesteld; met het ontwerpen van een behoorlijk uitgewerkt definitief plan zonder terreinopnemingen zoude een bedrag van $f$ 12.000.- gemoeid zijn. De toenmalige Minister van Koloniën gaf als zijn voorloopige meening te kennen dat ook dit plan wegens de hooge kosten in de toenmalige omstandigheden niet aannemelijk was."

Naar ik meen behoeft dit voorstel geene lange overweging, als zijnde het van begin af weinig aanbevelenswaardig. Het maken van vrijwel stilstaand, vermoedelijk met organische stoffen overrijk bedeeld water, niet in kleine hoeveelheid in het laboratorium, maar in groote hoeveelheid jaar in jaar uit in den dagelijkschen sleur der practijk, tot goed leidingwater, acht ik alleen in uitzonderingsgevallen mogelijk. 
$4^{\circ}$. Door mij is voorgesteld waterwinning uit de Para. Sedert heb ik bevonden dat de heeren van Hasselt en Hoogesteger in hun rapport reeds hebben geschreven:

„De Parakreek zal, wat haar benedengedeelte betreft, in den grooten drogen tijd ook nog sterk aan de werking van ebbe en vloed onderhevig zijn. Het verschil tusschen normaal hoog- en laagwater bedraagt te Paramaribo toch immers $1.80 \mathrm{M}$. zijn.

Dit verschil zal bij springvloeden nog veel aanzienlijker kunnen

Toch biedt de Parakreek boven de hiervoren genoemde groote rivieren veel meer zekerheid.

Nagegaan zal moeten worden, in den loop van een jaar, wat de afvoerverhoudingen en hoedanigheid van dit water op verschillende plaatsen van den rivierloop is en in welk punt van den rivierloop eventueel eene geschikte plaats voor prise d'eau is te vinden; waarbij in het oog dient gehouden te worden dat de drukbuisleiding naar Paramaribo langs een gebaand tracé moet gevoerd worden.

Behalve de kans van een te groot zoutgehalte en de middelen, welke voor elk rivierwater aangewend moeten worden, om dit voldoende te zuiveren, zal bij het rivierwater van Suriname nog een uitvoerig onderzoek ingesteld moeten worden naar middelen om dit te ontkleuren, daar uit de overgelegde stukken blijkt, dat deze ontkleuring waarschijnlijk niet zal kunnen worden verkregen door enkele sedimentatie en filtratie."

Wat dit laatste betreft, moge ik verwijzen naar het op dit punt alreeds in het Centraal laboratorium voor de volksgezondheid ingestelde onderzoek, waarover ik heb bericht in de W. I. Gids van 1924.

Om met zekerheid zoet water te verkrijgen, hebik voorgesteld het water aan de rivier te ontnemen bij Onoribo. Sedert bereikten mij berichten dat ook daar bij de laatste groote droogte het water zout bevonden is, maar onbeantwoord bleef mijne vraag of dit gedurende zoo langen tijd van elk etmaal het geval is geweest, dat geen tijd over bleef voor waterinneming; waarbij er op worde gewezen dat in Nederland ook groote plaatsen als Rotterdam slechts enkele uren per dag water kunnen verkrijgen ter voeding 
hunner waterleiding, zonder dat dit tot hinderlijke bezwaren aanleiding geeft.

In hoeverre de plaatselijke gesteldheid zou toelaten om desnoods eenige K.M. hooger de Para op te gaan, kan ik niet beoordeelen. Dit kan alleen door plaatselijk onderzoek worden uitgemaakt.

$5^{\circ}$. Aangezien de afstand tusschen den mond der Saramacca en het punt, alwaar deze rivier Paramaribo het meest nadert, groot is en bovendien ook het stroomgebied der Saramacca vrij groot, zoodat ik onderstel dat de waterafvoer belangrijk is, ware wellicht, indien het opdringen van het zoute water een werkelijk beletsel tegen waterwinning uit de Para zou blijken, na te gaan of op een geschikt punt aan de Saramacca water onttrokken zou kunnen worden. Door anderen vind ik deze rivier echter nog niet als winplaats genoemd, zoodat ik vermoed, dat er bezwaren bestaan, die mij nog niet bekend zijn.

$6^{\circ}$. Nadat ik in het Voorloopig rapport der heeren van Hasselt en Hoogesteger het navolgende had gelezen :

„Waar uit het bovenstaande blijkt, dat in de onmiddellijke omgeving der stad Paramaribo grondwater in voldoende hoeveelheid en van voldoende kwaliteit niet zal gevonden worden, schijnt de kans op succes grooter in de streek tusschen ca. 40 en 75 K.M. bezuiden Paramaribo. Deze ongeveer 35 K.M. breede strook heuvelland, welke tot ruim $30 \mathrm{M}$. boven Surinaamsch peil oploopt en welke nagenoeg parallel aan de kust loopt, zijn de zoogenaamde Savannen.

Deze Savannen bestaan in hoofdzaak uit een door verwering van graniet ontstanen zandgrond. De nieuwe spoorbaan van Paramaribo naar Dam gebruikt het Savannazand voor ballast. Het is de eenige door de spoorbaan doorsneden streek, waar zand is aangetroffen.

Ofschoon aan ons van bevoegde zijde werd medegedeeld, dat dit zand weinig doorlaatbaar is voor water, zoo geeft de omstandigheid, dat de Savannen zijn groote open vlakten met gras begroeid en deze dus voor andere gewassen het water niet genoeg in den bovengrond vasthouden, ons aanleiding, om te concludeeren, dat de kans niet is uitgesloten, dat deze strook ter breedte van ca. 
35 K.M. een uitstekend infiltratiegebied is. Vooral wanneer men daarbij bedenkt, dat bij den grooten regenval in Suriname een betrekkelijk geringe infiltratie reeds voldoende is, om te voorzien in de behoeften van eene waterleiding.

Nadere onderzoekingen zullen natuurlijk uit moeten maken, of deze conclusie juist is.

Zwampen, waarin het water bederft, en bruin gekleurd wordt, komen in het algemeen in de Savannenstreek niet voor, terwijl de omstandigheid, dat in de lagere gedeelten verschillende kreken haar oorsprong hebben en deze ook gedurende den drogen tijd geregeld water afvoeren, eene aanwijzing geeft niet alleen, dat hier infiltratie plaats heeft, maar ook dat het water zich langzaam genoeg beweegt, om in den natten tijd de vorming van een reserve voor den drogen tijd mogelijk te maken.

Dit alles in verband met de groote oppervlakte der Savannen, maakt dat hier allicht alle factoren aanwezig zijn, om vermoedelijk voldoende en goed grondwater te kunnen verkrijgen.

Omtrent dit Savanna-zand schrijft de heer Jhr. J. C. van Reigersberg Versluys in zijne „Aanteekeningen betreffende spoorwegaanleg in Suriname" De Ingenieur $A^{\circ}$ 1908, blz. 137:

„Savannazand. Dit is het reeds vermelde materiaal dat als ballast dient.

Het is spierwit, zeer zwaar en daardoor niet aan stuiven onderhevig. Op taluds worden de zeer fijne deeltjes uitgespoeld. De zwaardere blijven echter liggen. De vegetatie op dit zand is zeer gering en gelijkt veel op die der Brabantsche heiden.

Op blz. 138:

Hierbij kwam dat de eerste zandsavanna aangetroffen wordt een drietal K.M. bezuiden de politiepost Republiek. Ook al was de Para geheel onbewoond geweest dan zou toch daarheen de baan zijn gericht, terwille van de nergens anders vindbare ballast."

De zanderijen zijn bij K.M. 44 en K.M. 64. De mogelijkheid is niet uitgesloten, dat diepboringen b.v. op 30 K.M. bezuiden Paramaribo en nabij de spoorbaan goed en voldoende water geven. De diepere grondlagen aldaar zouden dan hare voeding vinden in het zuidelijk gelegen Savanna-heuvelland. Het is dus van het grootste belang om een geohydrologisch profiel te krijgen ten zuiden van Paramaribo in de richting noord-zuid b.v. langs de spoorbaan.

Daarvoor zouden langs de spoorbaan b.v. te beginnen bij K.M. 25 en vervolgens ongeveer elke 5 K.M. zuidelijker tot en met K.M. 60 diepboringen verricht moeten worden.

De geologische formatie van het Surinaamsche laag- en heuvel- 
land blijft in de richting oost-west nagenoeg gelijk, verandert echter zeer snel in de richting noord-zuid.

Indien door middel van grondboringen bewezen werd, dat b.v. 40 à 45 K.M. ten zuiden van Paramaribo goed grondwater in voldoende hoeveelheid kan gewonnen worden, dan biedt de pas aangelegde spoorbaan het groote voordeel, dat daarlangs een drukbuisleiding kan gelegd worden om het water van de prise d'eau naar Paramaribo te transporteeren. Ware geen spoorbaan of weg aanwezig, dan zoude het praktisch niet mogelijk zijn eventueel goed grondwater uit de binnenlanden naar de stad te voeren. Eventueel zouden de verschillende nederzettingen langs de spoorbaan uit de drukbuisleiding eveneens van drinkwater voorzien kunnen worden."

trof het mij zeer toen ik in het hiervoor reeds meer aangehaalde Rapport betreffende de drinkwatervoorziening van Paramaribo van den Directeur van het Departement van Openbare Werken en Verkeer las:

„teneinde met eenige meerdere zekerheid te kunnen vaststellen de diepte van het onverweerde gesteente (bedrock) te Paramaribo, (zijn) een tweetal ondiepe boringen met het Bankatoestel verricht, een bij Post Republiek (K.M. 41) en één bij K.M. 36 van de spoorbaan.

De eerste boring moest ter diepte van ruim $28 \mathrm{M}$. worden gestaakt omdat het onmogelijk was de buizen dieper te doen zakken in de aangeboorde taaie kleilaag; deze grondsoort is naar alle waarschijnlijkheid verweerd oorspronkelijk gesteente. In het witte zand tusschen de kleilagen in gelegen, werd een krachtige stroom drinkbaar water geconstateerd, hetwelk bij den bouw van een nieuwe spoorbrug over de nabijgelegen Coropinakreek het werkvolk voor drinkwater heeft gediend.

Bij de tweede boring nabij K.M. 36 van de spoorbaan moest met boren worden opgehouden op $38.50 \mathrm{M}$. beneden maaiveld wegens gebrek aan meerdere boorbuizen. De bedrock werd hier evenmin bereikt. Sterk waterhoudende zandlagen werden ook hier doorsneden."

Het is dus hoogst waarschijnlijk dat op ongeveer 36 K.M. van Paramaribo goed grondwater gewonnen zal kunnen worden. Maar dan moet ook daarop in de eerste plaats alle aandacht gevestigd worden. 
Het bezwaar dat de leiding van het pompstation naar den watertoren in de stad dan nog langer wordt dan de door mij voor de Para-waterleiding reeds voorgestelde, acht ik niet overwegend - zelfs van vrij geringe beteekenis tegenover de voordeelen, die eene waterleiding met waterwinning uit deze aardlagen zou geven ${ }^{\mathbf{1}}$ ). Bij nader inzien neem ik terug wat ik in de W. I. Gids, destijds nog niet het vraagstuk zoo van alle kanten bekeken hebbende, schreef:

„Vast staat reeds door vroegere onderzoekingen, dat grondwater niet verkrijgbaar is op korteren afstand van de stad dan 50 K.M. (bij Republiek). Het zal dus eene rivierwaterleiding moeten worden."

De directe meerdere exploitatiekosten, welke het gevolg zullen zijn van de noodzakelijkheid om het water aan het pompstation hooger op te persen, ter overwinning van het meerdere wrijvingsverlies in de langere leiding zullen niet van beteekenis zijn. Daartegenover staat zeer waarschijnlijk dat het veel zuiverder water ook veel minder zal kosten aan arbeid en dus ook aan loonen voor zuivering en aan daarbij noodige chemicaliën.

De eenmalige aanlegkosten der werken zullen hooger zijn. Echter ook al weder niet zoo veel als wellicht op het eerste gezicht ondersteld zou worden. Volgens mijne in de West-Indische Gids van 1923 gepubliceerde en nimmer als onjuist aangevallen berekening van de kosten eener rivierwaterleiding, met wateronttrekking uit de Para, is de aanleg van dit werk, met:

eene transportleiding van het pompstation

naar de stad ter lengte van . . . . . . \pm 25 K.M. eene aanvoerleiding van de Para naar het

pompstation ter lengte van .. . . . \pm 6 K.M.

samen .. . . . \pm 31 K.M.

economisch nog alleszins mogelijk. Zelfs zou nog wel

1) Toen ik de waterleiding voor Zuid-Beveland tot stand bracht is ook zonder aarzelen besloten om de waterwinplaats te kiezen op $35 \mathrm{~K}$. M. van den hoofdwatertoren. In de praktijk is van geene bezwaren dientengevolge gebleken. 
$f$ 100.000.- meer dan het als kostprijs geraamde bedrag van $f$ 1.600.000.- uitgegeven kunnen worden ${ }^{1}$ ). Aannemende dat de groote transportleiding ongeveer $f 25.000$ per K.M. in het werk zal kosten, zouden de meerdere kosten ongeveer $f 125.000$ bedragen. Maar anderzijds zal bespaard kunnen worden omdat verschillende bij het gebruiken van rivierwater noodige bezinkingsbassins en filterbassins niet gebouwd zullen behoeven te worden of althans veel kleiner zullen kunnen worden gemaakt.

Op al deze gronden meen ik dat financiëel de aanleg eener waterleiding uit de uitloopers der Savannen naar de stad volstrekt niet, zonder verder onderzoek, onmogelijk behoeft te worden geacht. De zaak is zeker zoodanig verder onderzoek waard.

Resumeerende veroorloof ik mij als mijne meening uit te spreken dat als eerstvolgende daad om te komen tot eene waterleiding voor Paramaribo gewenscht is:

$1^{\circ}$. het ter plaatse nagaan wat van de diepboringen in Demerara geworden is;

$2^{\circ}$. het verzamelen uit de archieven te Paramaribo van al wat daarin nog omtrent de diepboring op het Sivaplein voorkomt;

$3^{\circ}$. het instellen van het eenvoudige onderzoek, dat de heer Bolten voorstelt om de bruikbaarheid van de door hem aangegeven schelprits als waterwinplaats te toetsen;

$4^{\circ}$. het verzamelen van alle nog verkrijgbare gegevens omtrent het indringen van zeewater, althans brak water, in de Para en de Saramacca tijdens de laatste groote droogte;

$5^{\circ}$. het verzamelen van alle gegevens, welke nog in de archieven te Paramaribo gevonden kunnen worden omtrent de uitkomsten der bij K.M. 36 van den spoorweg destijds verrichte boring, alsmede het instellen van een nader onderzoek naar de uitgestrektheid en het watergevend vermogen van de daar aangeboorde zandlagen.

1) $\mathrm{Bij}$ de tegenwoordige materiaalprijzen, die lager zijn dan toen ik de berekening maakte, zou het werk wel niet meer dan $f 1.500 .000,-$ vorderen. Maar daarop worde niet gesteund. Over een jaar zijn de prijzen misschien wederom gestegen. 
Voor dit laatste zal waarschijnlijk, maar alleen ter plaatse zelve zal daarover nader geoordeeld kunnen worden, noodig zijn het doen van eenige ondiepe boringen, met proefpomping, en scheikundig en bacteriologisch onderzoek van het opgepompte water.

Echter zou ik bij dit onderzoek in geenen deele zoo ver willen gaan als de heeren van Hasselt en Hoogesteger, die voorstellen:

„Langs de spoorbaan tot op het vaste gesteente (bedrock) diepboringen met onderzoek der watervoerende lagen te verrichten nabij K. M. 25, 30, 35, 40, 45, 50, 55 en 60 , welk hoofdonderzoek door een détailonderzoek kan aangevuld worden."

Afgezien nog daarvan dat de goede tijd voor het tot stand brengen van een groot werk, door al dat onderzoeken vaak verloren gaat; de kosten van het door de heeren voorgestelde onderzoek zullen al heel weinig minder bedragen dan de aanlegkosten van een paar K.M. buisleiding. Het gaat hier nu eenmaal niet om het wetenschappelijk ongetwijfeld uiterst belangrijke vraagstuk der geologie en hydrologie van Suriname, maar om het tot stand brengen eener waterleiding voor Paramaribo.

Bij K.M. 36 van den spoorweg was men op $36.5 \mathrm{M}^{1}$. diepte reeds lang door de watervoerende laag heen. Deze ligt dus ondiep. Hoe diep weet ik niet. Is dit eenmaal bekend, dan kan worden nagegaan of er aannemelijke redenen bestaan om te verwachten dat die laag bijv. bij K.M. 30 ook nog niet te diep zal liggen en dan doe men ook daar nog eens eene ondiepe boring. Misschien kan men dan nog eens dichter bij de stad gaan. Het opzoeken van de „,bedrock" is echter bij dit onderzoek allerminst noodig wel noodig daarentegen is het om er terdege op te letten hoeveel het watervoerend vermogen afneemt, naarmate men verder Noordwaarts gaat. Dat raakt de hoofdzaak.

$\mathrm{Al}$ deze onderzoekingen te zamen zullen niet langer dan enkele maanden behoeven te vorderen. Dat zij het best in den drogen tijd worden verricht is duidelijk. Waarschijnlijk zal daarna voldoende zekerheid zijn verkregen om te kunnen besluiten over de plaats, waar het voor Paramari- 
bo benoodigde water veilig kan worden betrokken en zal het financieele vraagstuk aan de orde kunnen komen om het geld bijeen te brengen voor het eenvoudige samenstel van (putten?), motoren, pompen, (filters?), buizen en watertoren, die ten slotte in technischen zin de waterleiding van Paramaribo zullen vormen.

Goes, 7 Augustus 1927. 